\title{
$\$$ Research Square \\ A new method of bio-catalytic surface modification for microbial desalination cell
}

\section{Research}

Keywords:

Posted Date: November 5th, 2020

DOl: https://doi.org/10.21203/rs.3.rs-41414/v3

License: (c) (i) This work is licensed under a Creative Commons Attribution 4.0 International License.

Read Full License

Version of Record: A version of this preprint was published at International Journal of Renewable Energy Development on December 26th, 2020. See the published version at https://doi.org/10.14710/ijred.0.34235. 


\section{Abstract}

The authors have requested that this preprint be withdrawn due to author disagreement.

\section{Full Text}

The authors have withdrawn this preprint from Research Square. 